\title{
УМОВНО-ДОСТРОКОВЕ ЗВІЛЬНЕННЯ ЗАСУДЖЕНОГО ВІД ПОДАЛЬШОГО ВІДБУВАННЯ ПОКАРАННЯ У ВИДІ ПОЗБАВЛЕННЯ ВОЛІ ПІД НАГЛЯД ЯК ФОРМА ПРОГРЕСИВНОЇ СИСТЕМИ ВИКОНАННЯ ТА ВІДБУВАННЯ ПОКАРАННЯ У ВИДІ ПОЗБАВЛЕННЯ ВОЛІ: ДОКТРИНАЛЬНІ АСПЕКТИ
}

У статті висвітлюються та аналізуються доктринальні аспекти щодо доцільності та необхідності існування такої форми прогресивної системи виконання та відбування покарання у вигляді позбавлення волі, як умовно-дострокове звільнення засудженого від подальшого відбування покарання у вигляді позбавлення волі під нагляд.

Чинне кримінальне та кримінально-виконавче законодавство поєднує у собі суворість покарання щодо осіб, що мають підвищену суспільну небезпеку, які вчинили кримінальні правопорушення, і водночас регламентують різноманітні заходи пом'якшення відповідальності та звільнення від подальшого відбування покарання засуджених у випадках, коли їх виправлення досягається до закінчення встановленого вироком суду терміну покарання. Актуальним $\epsilon$ не тільки застосування кари, але й виділення із загального числа засуджених осіб, які усвідомили згубність кримінально протиправної поведінки і не потребують повного відбування призначеного судом покарання, а їх подальше виправлення можливе і без ізоляції від суспільства.

3'ясовано, що наявні складнощі у розмежуванні матеріальних підстав застосування інститутів, передбачених сm. $81 \mathrm{ma} \mathrm{cm.} 82$ КК України. Доведено, що існування умовно-дострокового звільнення засудженого від подальшого відбування покарання у вигляді позбавлення волі під нагляд дасть змогу уникнути суперечливих доктринальних суджень, різних наукових тлумачень щодо інституту умовно-дострокового звільнення, а також займе перехідне соціально-правове положення між заміною покарання на більш м'яке та умовно-достроковим звільненням.

Автори зазначають, що умовно-дострокове звільнення під нагляд стане певним альтернативним видом дострокового звільнення від подальшого відбування покарання у вигляді позбавлення волі на певний строк. У межах поетапної реалізації прогресивної системи виконання та відбування покарання ці різновиди припинення подальшого перебування особи в ізоляціі шляхом заміни позбавлення волі на інше більш м'яке покарання - умовно-дострокове звільнення під нагляд, умовно-дострокове звільнення без встановлення

\section{Гритенко О. А., Чекмарьова І. М.}

додаткових вимог, крім однієї, не вчиняти злочин у невідбутий термін покарання, - дозволять зменшити за часом та колом осіб наслідки негативного впливу самого факту перебування особи в ізоляціі, а також дадуть змогу удосконалити механізм поетапної реалізації процесу виправлення в частині формування та закріплення позитивних змін у свідомості (підсвідомості) та поведінці засудженої особи. Доведення виправлення стане можливим за умови перебування особи у вільному суспільстві, відчуваючи всі загрози життя у сучасній державі, де реформуються практично всі сфери життєдіяльності людини. Позитивне законодавче рішення щодо доцільності існування певного різновиду умовно-дострокового звільнення поширить сферу реалізації прогресивної системи загалом, надасть більшої чіткості та повноти у поетапності досягнення мети покарання.

Ключові слова: відбування, виконання, засуджені, звільнення, нагляд, позбавлення волі, прогресивна система, покарання, умовно-дострокове.

Hrytenko O. A., Chekmarova I. M. Parole for convicted person from completion of their sentence of deprivation of liberty by means of supervision as a form of progressive system of sentencing and correctional system: doctrinal aspects

The article highlights and analyzes the doctrinal aspects of the expediency and necessity of such a form of progressive system of execution and serving a sentence in the form of imprisonment, as parole from further serving a sentence of imprisonment under supervision.

The current criminal and penitentiary legislation combine the severity of punishment for persons with increased public danger who have committed criminal offenses, and at the same time regulates various measures to mitigate the responsibility and release from further serving of sentences in cases where they correction is achieved before the expiration of the sentence established by the court sentence. It is important not only to apply punishment, but also to select from the total number

(ㄷ Гритенко О. А., Чекмарьова І. М., 2020 
of convicted persons who have realized the perniciousness of criminally illegal behaviour and do not require full service of the sentence imposed by the court, and their further correction is possible without isolation from society.

It was found that there are difficulties in distinguishing the material grounds for the application of the institutions provided for in Art. 81 and Art. 82 of the Criminal Code of Ukraine. It is proved that the existence of parole from further imprisonment will avoid contradictory doctrinal judgments, different scientific interpretations of the institution of parole, and will take a transitional socio-legal position between the replacement of the sentence by a longer term.

The authors note that parole will be a certain alternative type of early release from further imprisonment for a certain period. As part of the phased implementation of a progressive system of execution and serving a sentence, these types of termination of further detention in person by replacing imprisonment with another more lenient punishment - parole, parole without additional requirements, except for one - not to commit a crime in the unserved term of punishment - will reduce the time and circle of persons the consequences of the negative impact of the fact of being in isolation, as well as improve the mechanism of gradual implementation of the correction process in terms of forming and consolidating positive changes in consciousness persons. Proving correction will be possible provided that the person is in a free society, feeling all the threats to life in the modern state, where almost all spheres of human life are being reformed. A positive legislative decision on the expediency of the existence of a certain type of parole will expand the scope of the progressive system as a whole, provide greater clarity and completeness in the gradual achievement of the goal of punishment.

Key words: serving, execution, convicts, release, supervision, imprisonment, progressive system, punish ment, conditional-early.

Постановка проблеми та її актуальність. Чинне кримінальне та кримінально-виконавче законодавство поєднує у собі суворість покарання щодо осіб, що мають підвищену суспільну небезпеку, які вчинили кримінальні правопорушення, і водночас регламентують різноманітні заходи пом'якшення відповідальності та звільнення від подальшого відбування покарання засуджених у випадках, коли їх виправлення досягається до закінчення встановленого вироком суду терміну покарання. Актуальним $\epsilon$ не тільки застосування кари, але й виділення із загального числа засуджених осіб, які усвідомили згубність кримінально протиправної поведінки і не потребують повного відбування призначеного судом покарання, а їх подальше виправлення можливе і без ізоляції від суспільства.
Зокрема, такі інститути звільнення від відбування покарання, які передбачені ст. ст. 81, 82 КК України, $\epsilon$ однією з форм припинення відбування покарання i $\epsilon$ своєрідними актами правосуддя, державного заохочення, мірою позитивної суспільно-політичної, морально-етичної та юридичної оцінки, позитивних змін у поведінці засудженого, що відбулися в ньому в період відбування покарання.

Ці інститути, поєднуючи методи переконання i примусу, висловлюють гуманність i соціально-політичну раціональність як принципи організації, соціальної системи впливу на кримінальну протиправність у розвиненому громадянському суспільстві.

Незважаючи на те, що умовно-достроково можуть бути звільнені тільки засуджені, які впевнено стали на шлях виправлення, така категорія осіб вимагає постійного нагляду, і тут допоміжним міг би стати такий вид звільнення від відбування покарання, як умовно-дострокове звільнення засудженого від подальшого відбування покарання у вигляді позбавлення волі під нагляд. Отже, вказане зумовлює з'ясування, зокрема на доктринальному рівні, доцільності та необхідності умовно-дострокового звільнення від подальшого відбування покарання у вигляді позбавлення волі під нагляд.

Аналіз останніх досліджень і публікацій. Вагомий внесок у розробку досліджуваної проблематики здійснили такі вітчизняні вчені, як: В.В. Василевич, В.В. Гуменюк, О.П. Горох, О.В. Дащенко, Д.В. Козначеєва, О.М. Кревсун, Т.О. Лесниєвська-Костарева, А.І. Марчук, Н.М. Пісоцька, Є.О. Письменський, М.В. Романов, В.В. Федусік, Н.Б. Хлистова, П.В. Хряпінський, Г.Ф. Хохряков, Д.А Щерба, Ю.К. Якимович, І.С. Яковець та ін.

Мета статті полягає в дослідженні доктринальних положень щодо доцільності та необхідності існування такої форми прогресивної системи виконання та відбування покарання у вигляді позбавлення волі, як умовно-дострокове звільнення засудженого від подальшого відбування покарання у вигляді позбавлення волі під нагляд.

Виклад основного матеріалу. Безумовним $\epsilon$ те, що суд, призначаючи мінімально необхідний для досягнення цілей строк покарання, не виключає тієї ситуації, що для певних осіб і цей термін може бути завеликим. Якщо ж виправлення особи досягається до завершення терміну покарання, його подальше виконання втрачає сенс. Маємо погодитися із тим, що якщо мета покарання може бути досягнута ще до закінчення призначеного 


\section{Актуальні проблеми \\ історико-правової науки}

судом строку покарання, то в подальшому його виконанні відпадає необхідність [14, с. 10]. Саме з огляду на це закон передбачає можливість застосування судом умовно-дострокового звільнення від відбування покарання.

Саме інститут умовно-дострокового звільнення дозволяє корегувати цю ситуацію стосовно засуджених, які відбувають одне із найсуворіших покарань - позбавлення волі на певний строк. Загальновизнаним є той факт, що умовно-дострокове звільнення від відбування покарання $\epsilon$ найбільш застосовуваним видом звільнення, зважаючи на його суттєві стимулюючі властивості та особливості характеру кримінально-правового та кримінально-виконавчого впливу в головному спрямуванні до досягнення мети покарання в оптимальні терміни та з мінімальними негативними наслідками для держави, суспільства та особи засудженого. Найчастіше суди вирішують питання щодо умовно-дострокового звільнення від відбування покарання саме щодо засуджених до покарання у вигляді позбавлення волі $(83,1 \%)$ [3, с. 20]. Проте широке застосування умовно-дострокового звільнення до засуджених осіб (майже 25\%) [9, с. 166] посилює актуальність не лише питання щодо якості застосування цього виду звільнення на практиці, але й свідчить про відносну його поширеність. Потенційні стимулюючі можливості такого інституту можуть бути набагато вищими.

Це не остаточний, а умовний вид звільнення, пов'язаний з пред'явленням особі визначених законом вимог, які вона має виконати протягом певного іспитового строку. Ця вимога одна. Особа, до якої було застосовано умовно-дострокове звільнення від відбування покарання, протягом невідбутої частини покарання не повинна вчинити нового кримінального правопорушення. Порушення цієї вимоги тягне за собою не лише скасування застосованого судом звільнення від покарання, але й призначення покарання за сукупністю вироків, що у підсумку значно впливає на обсяг та вид покарання. Тож закон не передбачає ніяких обов'язків щодо особи, яка умовно-достроково звільнюється.

Традиційно в доктрині кримінального права саме на цій підставі визначають умовний характер дострокового звільнення, бо термін невідбутої частини покарання розглядається як випробувальний строк для звільненої особи, яка повинна остаточно підтвердити своє виправлення - не вчинити нового злочину упродовж цього терміну [7, с. 418]. Вважається, що покарання у разі застосування умовно-дострокового звільнення не анулюється, а лише його реальне виконання призупиняється. I лише після закінчення певного терміну, невідбутої частини покарання за умови невчинення нового злочину засуджений вважається таким, який відбув покарання, що становить фактично відбутий строк [13, с. 339-340].

Історія знає декілька різновидів дострокового звільнення із в'язниці. Зокрема, видатний кримінолог М.С. Таганцев наприкінці XIX - початку XX століття у своїх лекціях з кримінального права прискіпливо аналізує такі два підвиди дострокового звільнення від відбування призначеного судом покарання: безумовне дострокове звільнення, що $\epsilon$ відтворенням скорочення тюремною адміністрацією призначеного судом терміну покарання у вигляді ув'язнення на підставі сумлінної поведінки, ставлення до праці та відбуття певного строку покарання; та суто умовно-дострокове звільнення, що теж застосовується за наявності певних підстав, проте із суттєвою відмінністю - засуджений звільняється достроково за умови дотримання особливих вимог (правил поведінки) під час невідбутої частини строку покарання. Недотримання цих вимог було підставою для скасування звільнення і незарахування терміну перебування на волі у строк покарання, а отже, могло значно подовжити термін відбуття покарання загалом. Оскільки наявність таких умов суттєво погіршувала положення цих засуджених порівняно із тими, до яких застосовували безумовне звільнення, вимагалося отримання у засудженого згоди на застосування цього виду звільнення [12, с. 231-233]. Уже з перших років поновлення інституту умовно-дострокового звільнення (60-і роки попереднього століття) недоліком його застосування визнавалося те, що закон не передбачає можливості відміни судом рішення про застосування дострокового звільнення на підставі вчинення звільненим адміністративних правопорушень, щодо необхідності організації спеціального органу, який би мав здійснювати нагляд та контроль за поведінкою звільнених осіб тощо [1, с. 211-212].

Проблема доцільності посиленого нагляду та контролю за звільненими із місць позбавлення волі почала знову обговорюватися наприкінці попереднього століття - початку XXI ст. Так, зокрема, В.О. Меркулова, здійснюючи дослідження особливостей жінки як суб'єкта кримінальної відповідальності, звернула увагу на той факт, що здебільшого суди відмовляли у застосуванні умовно-дострокового звільнення засу- 
дженим жінкам, які під час відбування покарання у вигляді позбавлення волі на певний строк пройшли примусовий курс лікування від алкоголізму та наркоманії. На тій підставі, що не були впевненими у досягненні ними певного ступеня виправлення. Навіть за наявності декількох заохочень та відсутності стягнень. Безумовно, позитивне поводження в місцях позбавлення волі цих жінок не $є$ гарантією того, що згубна звичка не з'явиться знову після звільнення, коли потяг можуть спровокувати будь-які проблеми та негаразди в житті звільненої. Тож пропонувалося посилення правового режиму умовно-дострокового звільнення від покарання здійснити за рахунок покладання на особу відповідних додаткових зобов'язань, порушення яких мало б потягти скасування факту звільнення. За рахунок визначення обов'язкових додаткових вимог до поведінки такої категорії звільнених жінок пропонувалося розширити сферу застосування умовно-дострокового звільнення [8, с. 241].

Цю позицію надалі підтримав Д.А. Щерба, який цю проблему розглядав уже стосовно всіх засуджених. Він запропонував відмовитися від терміна «виправлення» із заміною його на словосполучення «суспільна небезпечність», що має розглядатися як підстава подовження процесу ресоціалізації засудженої особи і після відбуття нею покарання, а отже, i після дострокового звільнення, що у підсумку може застерегти від прийняття помилкового рішення щодо застосування умовно-дострокового звільнення [14, с. 16]. Останнім часом ця проблема практично стала невід'ємним складником усіх спеціальних досліджень з проблем застосування умовно-дострокового звільнення засуджених від відбування покарання у вигляді позбавлення волі. Навіть стосовно довічного позбавлення волі. Виходячи з того, що зовнішня поведінка засудженого далеко не завжди відповідає його внутрішньому складнику, оскільки доволі часто трапляються випадки пристосування до умов відбування покарання, дотримання режимних вимог, вітчизняні вчені останнім часом усе частіше звертають увагу на таку прогалину чинного законодавства, як відсутність законодавчих підстав для встановлення контролю з боку держави за засудженими, які звільняються умовно-достроково.

Доцільність ставитися до невідбутої частини покарання (у разі застосування умовно-дострокового звільнення) як до випробування засудженого обґрунтовують у своїх наукових дослідженнях О.В. Дащенко, Д.В. Козначеєва, Є.О. Письмен- ський. На думку вчених, встановлення додаткових вимог (умов, обов'язків) до поведінки звільненого посилює значення ефективності постпенітенціарного контролю. Лише у такий спосіб підвищиться соціальна корисність контрольного строку, буде реалізованою відповідність сутності звільнення та його назви $[4$, с. 4, 12; 5, с. 11; 9, с. 216]. Як справедливо зауважує Є.О. Письменський, істинну щирість певних вчинків можна перевірити лише з часом, контролюючи особу поза режимом виконання або відбування покарання. Відповідно, певний контроль повинен бути невід'ємним складником дотримання вимог у разі дострокового звільнення [9, с. 183; 10, с. 16].

Зокрема, Д.В. Козначеєва пропонує вважати іспитовий строк у разі умовно-дострокового звільнення таким періодом часу, коли закріплюються результати виправлення засудженого, здійснюється його ресоціалізація. Відповідно, доводиться доцільність покладання на звільненого певних обов'язків, які передбачені для звільнених від відбування покарання з випробуванням у ч. 1 ст. 76 КК. Підставами для скасування умовно-дострокового звільнення пропонується розглядати вчинення адміністративного правопорушення, яке посягає на громадський порядок чи громадську безпеку (за умови накладення стягнення), та систематичне невиконання звільненим покладених на нього судом обов'язків упродовж невідбутої частини покарання [5, с. 4, 10, 14, 15].

Серед останніх наукових досліджень, в яких розглядається це питання, є дисертація О.М. Кревсуна, що присвячена проблемам прогресивної системи виконання покарання у вигляді позбавлення волі на певний строк у виправних колоніях. Проте автор фактор відсутності впевненості в адміністрації у тому, що засуджений досяг необхідного ступеня виправлення пропонує компенсувати в інший спосіб. Висловлюється пропозиція щодо доцільності визначення в законі норм, відповідно до яких строк застосування до засудженого умовно-дострокового звільнення від відбування покарання у разі наявності підстав може бути відкладено на 15 днів. На думку автора, такий підхід мав би стимулювати правосвідому поведінку засуджених [6, с. 5]. Вважаємо цю позицію не бездоганною та суперечливою, оскільки засуджений має протягом доволі тривалого терміну відбування покарання поступово (поетапно) доводити своє виправлення, і якщо він не має стягнень адміністрація зобов'язана розглянути питання щодо застосування до цієї особи умовно-дострокового звільнення. Якщо ж існують 
не зняті, не погашені види стягнень, то і 15 діб не допоможуть [2].

Висновки. Підсумовуючи зазначене, маємо дійти висновку, що суперечливі доктринальні судження, різні наукові тлумачення щодо інституту умовно-дострокового звільнення, доцільності (недоцільності) вважати цей міждисциплінарний інститут формою прогресивної системи, складнощі у розмежуванні матеріальних підстав застосування інститутів, передбачених ст. 81 та ст. 82 КК, факт відмови законодавця від віднесення цих інститутів до системи заохочувальних заходів тощо, надають цій проблемі особливого значення. Якщо відштовхуватися від того, що доволі проблематичним $\epsilon$ досягнення виправлення в умовах ізоляції, визнати значний ступінь використання законодавцем оціночних понять, які практично нівелюють відмінності в оцінці основних показників, що доводять досягнення певного ступеня виправлення засудженою особою, та об'єктивно поширюють межі суб'єктивного розсуду адміністрації установи, суду, маємо дійти висновку, що потрібно формулювати міждисциплінарний інститут, який займе перехідне соціально-правове положення між заміною покарання на більш м'яке та умовно-достроковим звільненням.

Відповідно, окремим напрямом посилення стимулюючого значення умовно-дострокового звільнення через поширення сфери застосування $\epsilon$ виокремлення його підвиду - умовно-дострокового звільнення під нагляд з визначенням обов'язку дотримання певних умов поведінки. Це має розглядатися як певний альтернативний вид дострокового звільнення від подальшого відбування покарання у вигляді позбавлення волі на певний строк.

У межах поетапної реалізації прогресивної системи виконання та відбування покарання ці різновиди припинення подальшого перебування особи в ізоляції шляхом заміни позбавлення волі на інше більш м'яке покарання - умовно-дострокове звільнення під нагляд, умовно-дострокове звільнення без встановлення додаткових вимог, крім однієї, не вчиняти злочин у невідбутий термін покарання, - дозволять поширити сферу застосування дострокових видів звільнення з установи кримінально-виконавчої системи закритого типу, зменшити за часом та колом осіб наслідки негативного впливу самого факту перебування особи в ізоляції, а головне, дозволять удосконалити механізм поетапної реалізації процесу виправлення в частині формування та закріплення позитивних змін у свідомості (підсвідомості) та поведінці засудженої особи. Доведення виправлення стане можливим за умови перебування особи у вільному суспільстві, відчуваючи всі загрози життя у сучасній державі, де реформуються практично всі сфери життєдіяльності людини. Позитивне законодавче рішення щодо доцільності існування певного різновиду умовно-дострокового звільнення поширить сферу реалізації прогресивної системи загалом, надасть більшої чіткості та повноти у поетапності досягнення мети покарання.

Проблема поширення сфери застосування умовно-дострокового звільнення для законодавця у найближчий час стане нагальною. Вирішення питання у такий спосіб буде відповідати певній зарубіжній практиці - обов'язковості встановлення вимог (додаткових правил поведінки) щодо осіб, які достроково звільняються із в'язниць. Питання контролю та спостереження за цими особами має не лише попереджувальне значення, це основа для визнання необхідності надання допомоги у вирішенні складних соціальних питань [2, с. 375-377].

\section{Література}

1. Вышинская 3.А., Шлыков С.А. Эффективность условно-досрочного освобождения от наказания. Эффективность уголовно-правовых мер борьбы с преступностью. Москва : «Юридическая литератуpa», 1968. С. 164-213.

2. Гритенко О.А. Прогресивна система виконання та відбування покарання у вигляді позбавлення волі: теоретичні та правові аспекти : монографія. Одеса : Видавничий дім «Гельветика», 2020. 400 с.

3. Горох О.П. Звільнення від покарання та його відбування за кримінальним правом України : автореф. дис. на здобуття наук. ступ. д-ра юрид. наук : спец. 12.00.08. Київ : НАНУ Ін-т держави і права імені В.М. Корецького, 2019. 40 с.

4. Дащенко О.В. Умовно-дострокове звільнення від відбування покарання неповнолітніх : автореф. дис. на здобуття наук. ступ. канд. юрид. наук : спец. 12.00.08. Запоріжжя, 2009. 21 с.

5. Козначеєва Д.В. Умовно-дострокове звільнення від відбування покарання : автореф. дис. на здобуття наук. ступ. канд. юрид. наук : спец. 12.00.08. Харків, 2011. 20 с.

6. Кревсун О.М. Прогресивна система виконання покарання у вигляді позбавлення волі на певний строк у виправних колоніях : автореф. дис. на здобуття наук. ступ. канд. юрид. наук : 12.00.08. Харків : ХНУВС, 2016. 20 с.

7. Кримінальне право України. Загальна частина. / За редакцією П.С. Матишевського, П.А. Андруш- 
ка, С.Д. Шапченка. Київ : Юрінком Іінтер, 1998. $606 \mathrm{c}$.

8. Меркулова В.О. Жінка як суб'єкт кримінальної відповідальності : монографія. Вид. 2-ге. Одеса : НДРВВ ОЮІ НУВС, 2003. 281 с.

9. Письменський Є.О. Звільнення від покарання та його відбування: проблеми кримінального законодавства та практики його застосування : монографія / перед. д-ра юрид. наук, доц. М.І. Хавронюка ; наук. ред. д-р юрид. наук, проф. 0.0. Дудоров. Луганськ : ТОВ «Віртуальна реальність», 2011. 388 с.

10. Письменський Є.О. Теоретико-прикладні проблеми звільнення від покарання та його відбування за кримінальним правом України : автореф. дис. на здобуття наук. ступ. д-ра юрид. наук : спец. 12.00.08. Київ : КНУ ім. Тараса Шевченка. 39 с.

11. Романов М.В. Звільнення від відбування покарання : навчальний посібник. Харків : Право, 2012. 89 c.

12. Таганцев Н.С. Русское уголовное право. Лекции. Часть общая. В 2 т. Т. 2. Москва : Наука, 1994. 393 c.

13. Уголовное право Украины. Общая часть. Изд. 2-е перер. и доп. / Под ред. М.И. Бажанова, В.В. Сташиса, В.Я. Тация. Харьков : Право, 1998. 400 с.

14. Щерба Д.А. Условно-досрочное освобождение от отбывания наказания: вопросы теории и практики : автореферат дис. на соискание уч. степени канд. юрид. наук : спец. 12.00.08. Владивосток, 2007. 21 c.
15. Яковець І. С. Умовно-дострокове звільнення та заміна невідбутої частини покарання більш м’яким : монографія. Москва, 2012. 210 с.

16. Звільнення від кримінальної відповідальності: кримінально-правові та кримінально-процесуальні аспекти : монографія / В.О. Меркулова, О.А. Гритенко, О.А. Марченко ; за заг. ред. В.О. Меркулової. Одеса : Видавничий дім «Гельветика», 2019. 368 с.

17. Меркулова В.О. Звільнення від кримінальної відповідальності та покарання: відповідність реформування загальної частини кримінального законодавства України принципам кримінального права. Південноукраїнський правничий часопис. 2016. № 2. С. 25-30.

Гритенко О. А., https://orcid.org/0000-0003-1376-6956 кандидат юридичних наук, доцент, професор кафедри кримінального права та кримінології

Одеського державного університету внутрішніх справ

Чекмарьова І. М., https://orcid.org/0000-0003-3167-2144 кандидат юридичних наук, доцент кафедри кримінального права та кримінології

Одеського державного університету внутрішніх справ 